\title{
IMPACT OF HUMAN CAPITAL ON PRODUCTIVITY GROWTH IN DIFFERENT LABOUR-SKILLED BRANCHES*
}

\author{
Domicián MÁTÉ \\ (Received: 20 November 2013; revision received: 10 April 2014; \\ accepted: 18 July 2014)
}

The primary objective of this study is to analyse the impact of human capital accumulation on productivity growth in a sectoral approach. In our estimations, we followed a specific taxonomy to identify the features of output and employment growth tendencies in four different labour-skilled branches in OECD countries. Besides determining the differences of output and labour structure by standard descriptive statistics, we used a dynamic panel regression method to investigate the connection between physical and human capital, employment, and productivity growth in each sector. All in all, we found an increasing role of human capital (HC) from the period between 1985 and 2007. Analysing the time series panel data of these countries, our results also yield valid relationships between the level of education and productivity growth.

Keywords: human capital, labour demand, productivity changes, sectoral approach

JEL classification indices: E25, J24, L16

* This research was supported in the framework of the TÁMOP 4.2.4. A/2-11-1-2012-0001 "National Excellence Program - Elaborating and operating an inland student and researcher personal support system" project and co-financed by the European Social Fund.

Domicián Máté, Assistant Professor at the Accounting and Financial Department, Faculty of Economics and Business Administration, University of Debrecen, Hungary.

E-mail: domician.mate@econ.unideb.hu 


\section{INTRODUCTION}

The contribution of labour to economic growth became especially popular in historical research after the rise of human capital theories advocated by Schultz (1961) and Becker (1964), and growth theories first formalised by Solow (1956). Later, as Nakamura (1981: 263) remarks, historians have tended to feature this human factor as the central and critical instrument for the achievement of progress and the betterment of our life, and he defines human capital as "labour, managerial skills, and entrepreneurial and innovative abilities - plus such physical attributes as health and strength."

Following the human capital (HC) revolution, a dichotomy took place in empirical models. In the 1980s, scholars mostly used the same proxies of HC in their work. It is often implicitly referred to as formal and informal education. Many social indicators such as educational enrolments, average years of education, and life expectancy became combined under a common term, "human capital". However, HC could also include factors such as the costs of raising children, health costs and ability, etc. (Leeuwen - Földvári 2008; Földvári et al. 2015).

Economists generally work with relatively easily collectable datasets that consist of a large number of countries to reflect affiliations between human capital and economic growth. From this perspective, the educational stock approach is one of the most popular. An early example of Denison (1967) included HC with categories such as age and education to account for the heterogeneity of labour. Other examinations were based on formal education substituted by enrolment ratios and literacy rates. For example, Ljungberg (2002) utilised historical data to look at this relationship in Sweden, while Nunes (2003) considered the cyclical behaviour of government expenditure on education in Portugal.

Parallel to this approach, other more comprehensive methods such as incomeand cost-based have also been developed. The latter (retrospective) technique is less extensive than the former (prospective) one. The cost-based approach was first developed by Kendrick (1976): it covered separately all costs of human capital and estimated $\mathrm{HC}$ for the USA by tangible (i.e. rearing a child until age 14) and intangible costs (health, safety, education, and the opportunity costs of students attending school, etc.). The prospective method is based on human capital theories that embodied the future earnings of individuals. Le et al. (2003) valued HC as the total income that could be generated in the labour market over a lifetime. Thus, some authors tried to integrate the (dis)advantages of these approaches. For example, Dagum - Slottje (2000) equated the monetary value of a person's human capital with the average lifetime earnings of the population (weighted by the level of HC). 
In our estimations, we follow a specific taxonomy to analyse different labourskilled branches. We assume that productivity growth varies in the performance of employees in each altered sector. Education is commonly defined as an investment that produces knowledge acquisition and increased productivity. However, this concept of education is very reductive, thus we assume that the level of education is one of the determinants that have an impact on economic growth per capita inversely and the direction of correlation depends on the skill intensity of labour in each sector.

The rest of this study is structured as follows. We will first briefly describe the sectoral features of output and employment growth tendencies in each OECD country with common descriptive statistics. Then we will present the results of our dynamic regression models with cross-industry panel data. The growth of HC is measured by the changes of average years of educational attainment to demonstrate how the given level of labour supply and the number of workers engaged ${ }^{1}$ might influence directly productivity growth in each sector. The paper ends with some policy implications and a conclusion. Our motivation is not only to suggest a feasible point of reference for policymakers to enhance better productivity growth performance in different sectors, but also to outline further research directions in this sectoral perspective.

\section{INDUSTRY STRUCTURE ANALYSIS AND TAXONOMY}

A unique database has been constructed for the analysis of economic and employment growth by the EU KLEMS (2003) Project. This includes measures of economic growth, productivity, employment creation, capital formation, etc. at the industry level for OECD countries from 1970 onwards. The last (March 2011) release of KLEMS provides data up to 2007 for a limited set of variables in different industries. Hence, in our estimations we expand the time series of Gross Value Added (GVA) ${ }^{2}$ at constant (1995) prices and empolyment in 56 industries $^{3}$ to calculate productivity and employment growth. In our dynamic models, we also need the share of investment within sectoral output for each country, which is available in KLEMS. The level of education will be generated by the average years of education over age 15 from the Barro - Lee (2014) Educational

1 Higher levels of education are positively correlated with greater labour participation and better economic performance.

2 GVA is used in economics as a measure of goods and services value produced in an industry or sector of an economy.

Industries were separated by Indicators of activities for Industry and Services, based on ISIC Rev 3. 
Attainment Dataset with the empirical approach of Caselli (2005). The robustness of our specifications will be tested by samples of the Penn World Table, included in Heston et al. (2006).

Many variables can determine and explain industrial growth performance. In our estimations, we followed van Ark et al. (2003) to identify the features of productivity tendencies. Their approach focused on general labour skills and was defined by educational attainment. In order to establish whether an industry in a particular country was high-, medium-, or low-skilled, the proportion of total employees for each skill group and industry was calculated for each country. ${ }^{4}$ The skill levels in Eurostat are based on the International Standard Classification of Education - 1976 (from ISCED 0 to 6). Table 1 lists our taxonomy divided into four different groups by labour-skill.

\subsection{Output and employment growth tendencies in various OECD countries}

This section looks at economic performance in the EU-15 and other OECD countries (AUS, CAN, KOR, JPY, and USA) contrasted with new EU member countries between 1980 and 2007, and 1995 and 2007. Economic growth is defined here as the growth in value added at constant prices (GVA).

As Figure 1 suggests, the greatest growth occurred in the high and high-intermediate-skilled (HS and HIS) branches and the lowest rate of growth was typical in the low-skilled (LIS and LS) industries. However, it appears that higher levels of skills are linked to better economic performance. The same holds in the EU-15 and other OECD countries (the only exception was France and Sweden). Cross country variables ranged from $1 \%$ to $12 \%$. However, the output growth varies substantially across countries; the rate of growth is roughly constant over long periods of time in all branches. In smaller EU countries (such as in Hungary), there was a much larger proportion of value added in the high-skilled industries than the EU-15 averages, except for the economic performance of the Czech Republic and Slovakia, where machinery and vehicle industries improved more markedly than the high-skilled industries (Figure 2).

Figure 3 reflects employment growth rates in the same industries. Here, similarities appear in the performances achieved of each sector and over time. The

4 If an industry within a country had a proportion of high skills at $20 \%$ higher than the average, it was classified as high skilled. If an industry within a country had a medium skill level higher than $5 \%$ above the average proportion of medium skills across all industries, it was classified as medium skill intensive. If on the other hand, neither of these conditions were fulfilled, the industry was classified as low skill intensive. 


\title{
Table 1
}

The sectoral taxonomy with ISIC Rev 3

\begin{abstract}
1. High-skilled (HS): Mineral oil refining, coke and nuclear fuel (23); Chemicals (24); Office machinery (30); Radio, television (TV) and communications equipment (32); Electronic valves and tubes (321); Telecommunication equipment (322); Radio and TV receivers (323); Financial intermediation, except insurance and pension funding (65); Insurance and pension funding, except compulsory social security (66); Activities auxiliary to financial intermediation (67); Real estate activities (70); Computer and related activities (72); R \& D (73); Other business services (74); Public administration and defence; compulsory social security (75); Education (80).
\end{abstract}

2. High-intermediate-skilled (HIS): Medical, precision \& optical instruments (33); Scientific instruments (331); Other instruments (33-331); Other transport equipment (35); Building and repairing of ships and boats (351); Aircraft and spacecraft (353); Railroad equipment and transport equipment (352+359); Electricity, gas and water supply (40-41); Air transport (62); Supporting and auxiliary transport activities; activities of travel agencies (63); Communications (64); Renting of machinery \& equipment (71); Health and social work (85).

3. Low-intermediate-skilled (LIS): Wood \& products of wood and cork (20); Pulp, paper \& paper products (21); Printing \& publishing (22); Fabricated metal products (28); Mechanical engineering (29); Electrical machinery and apparatus (31); Insulated wire (313); Other electrical machinery \& apparatus (31-313); Construction (45); Sale, maintenance and repair of motor vehicles and motorcycles; retail sale of automotive fuel (50); Wholesale trade and commission trade, except of motor vehicles and motorcycles (51); Retail trade, except of motor vehicles and motorcycles; repair of personal and household goods (52); Inland transport (60); Water transport (61).

4. Low-skilled (LS): Agriculture (01); Forestry (02); Fishing (05); Mining and quarrying (1014); Food, drink \& tobacco (15-16); Textiles (17); Clothing (18); Leather and footwear (19); Rubber \& plastics (25); Non-metallic mineral products (26); Basic metals (27); Motor vehicles (34); Furniture, miscellaneous manufacturing; recycling (36-37); Hotels \& catering (55); Other services (90-93).

Source: van Ark et al. (2003: 60-61).

average annual employment growth rates in the HS and HIS branches, in all examined countries, were greater than in the lower skilled ones. Furthermore, we should also claim that employment growth was controversially negative in several low-skilled (LS) industries, as it was in the EU-15 and other new member OECD countries. The only exception was Malta in the period 1995-2007 (Figure 4). Moreover, in Hungary, the employment growth in LIS branches was greater than the EU averages, feasibly thanks to the increasing role of machinery industries.

Industry structure can be described by using the distribution of value added and employment to the aggregate level of OECD countries. Table 2 represents value added and employment shares of the aggregate OECD performance over three years $(1980,1995,2007)$. In the OECD countries, in 1980, the major proportion of economic growth stemmed from the LS and LIS sectors (40\%), but by 


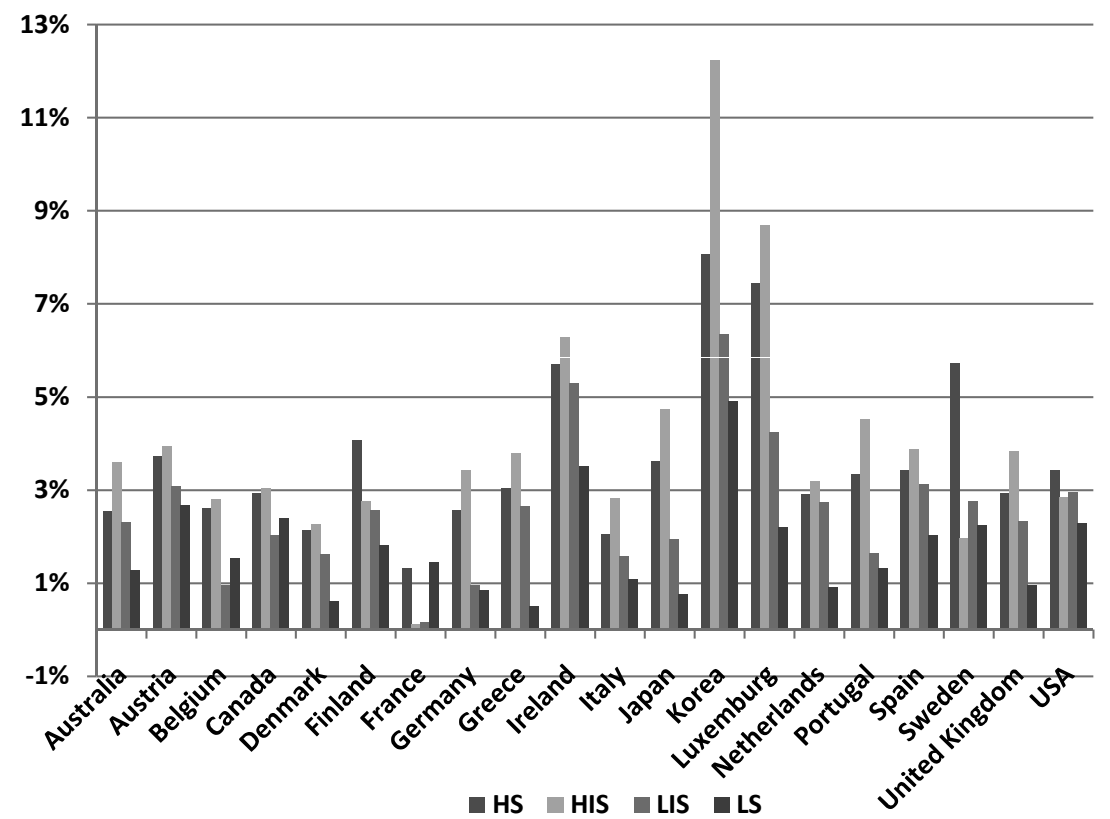

Figure 1. Average economic growth rates of OECD countries in each sector (1980-2007) Source: Own calculation based on EC KLEMS (2014).

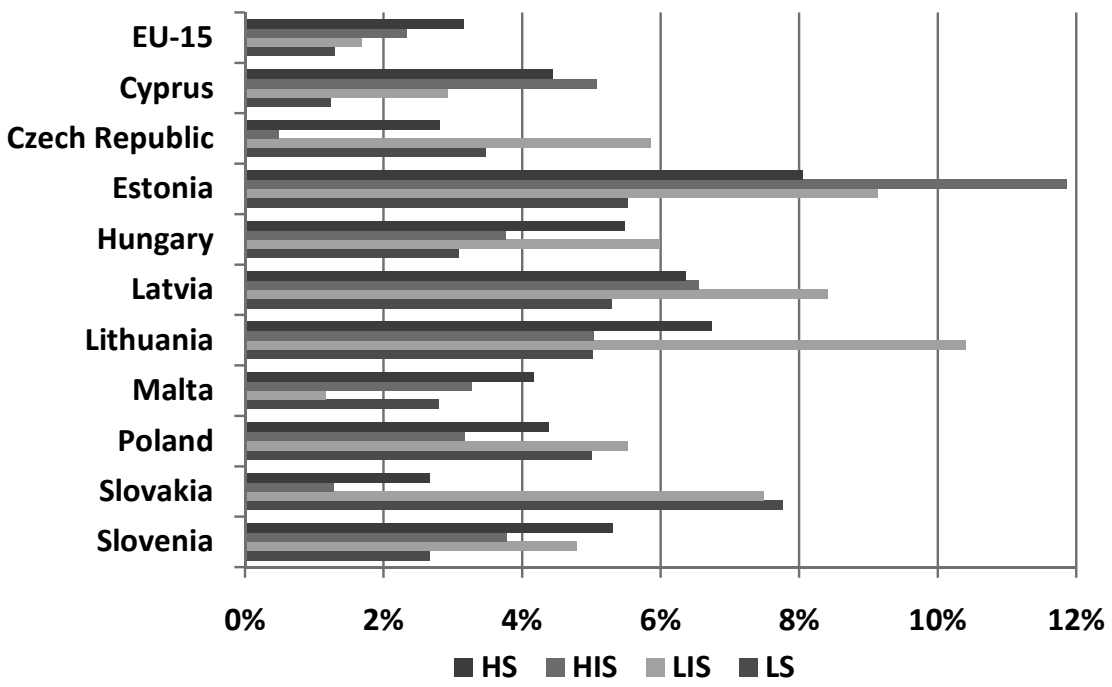

Figure 2. Average economic growth rates of new EU countries in each sector (1995-2007) Source: Own calculation based on EC KLEMS (2014). 


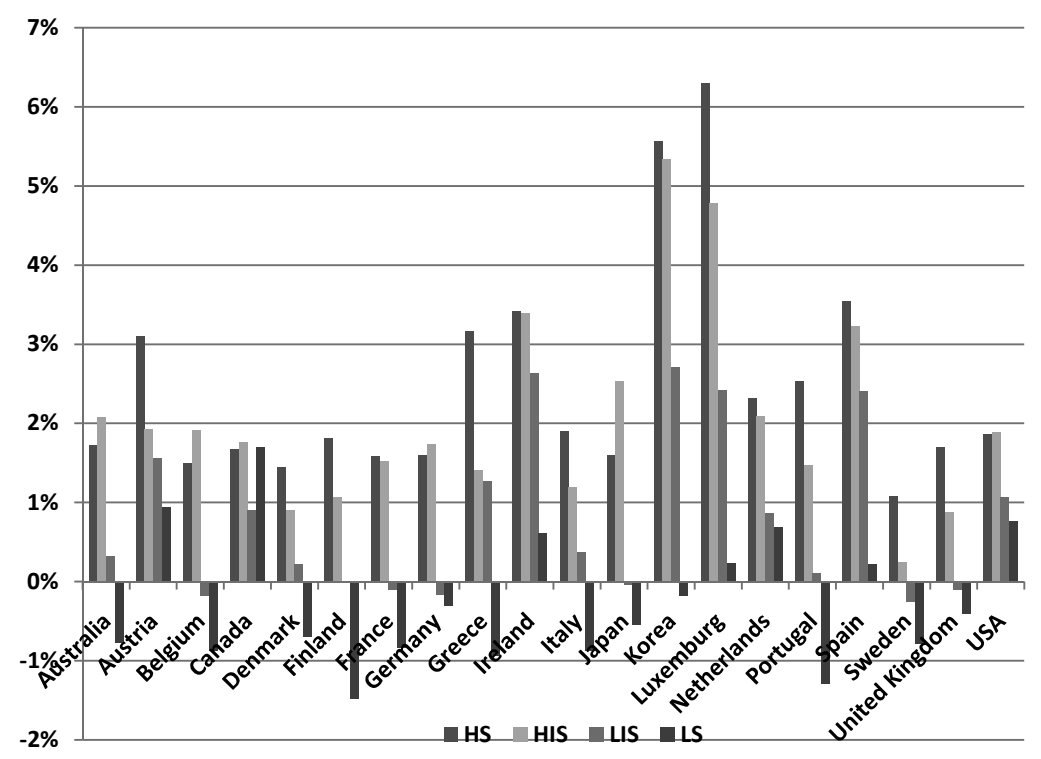

Figure 3. Average employment growth rates of OECD countries in each sector (1980-2007) Source: Own calculation based on EC KLEMS (2014).

2007, the high-skilled sectors were already enjoying the highest share (43\%). Although the total distribution position differs across the OECD, we can conclude that the high-skilled branches have achieved better economic growth than the lower ones. When we estimate employment performance, the same tendencies in sectoral shifts also seem to occur. From 1980 to 2007, the employment share evidently increased from $37 \%$ to $47 \%$ in the HS and HIS branches, but the decreasing employment of low-skilled workers was still higher than in our estimations.

\subsection{Dynamic productivity changes: an econometric evidence}

Now, we focus on a well-known human capital augmented implication. Our starting point is a standard Cobb-Douglas production function. Income at time $t$ can be written as

$$
Y_{t}=\left(A_{t} L_{t}\right)^{1-\alpha-\beta} K_{t}^{\alpha} H_{t}^{\beta}
$$

where $Y$ represents output, A is Total Factor Productivity (TFP), $K$ and $L$ are capital and labour, and $H$ is the stock of human capital. Thus, we assume a con- 


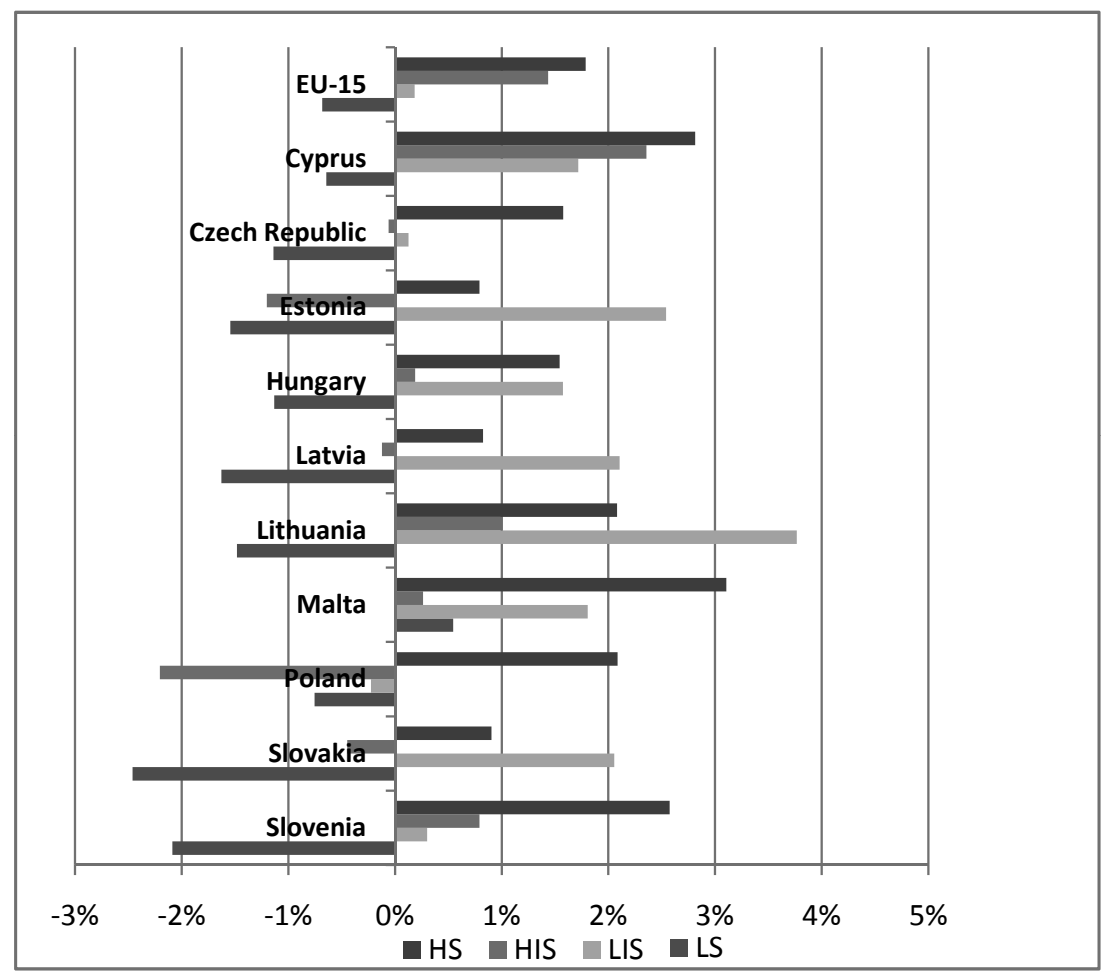

Figure 4. Average employment growth rates of new EU countries in each sector (1995-2007) Source: Own calculation based on EC KLEMS (2014).

\section{Table 2}

Output (GVA) and employment distribution of OECD countries in each labour-skilled sector (1980-2007)

\begin{tabular}{l|c|c|c|c}
\hline & High (HS) & High-intermediate (HIS) & Low-intermediate (LIS) & Low (LS) \\
\hline GVA (Output), \% & & & & \\
\hline $1980^{*}$ & 32.60 & 8.17 & 31.87 & 27.36 \\
\hline 1995 & 36.56 & 9.96 & 32.25 & 21.23 \\
\hline 2007 & 43.39 & 14.52 & 24.75 & 17.34 \\
\hline Employment, \% & & & & \\
\hline $1980^{*}$ & 24.96 & 12.24 & 32.90 & 29.91 \\
\hline 1995 & 28.88 & 13.83 & 31.65 & 25.64 \\
\hline 2007 & 31.86 & 15.09 & 29.87 & 23.18 \\
\hline
\end{tabular}

Source: Own calculation based on EC KLEMS (2014).

Note: *except CYP, CZE, EST, HUN, LTU, LTV, MLT, POL, SLK and SLV. 
stant return to scale and the magnitude of $(1-\alpha)$ should correspond roughly to the labour income share in total output, which is close to $2 / 3$ in most countries. All in all, this equation demonstrates how income can be influenced by the accumulation of human and physical capital, technological changes, and employment.

We express the role of human capital in this model. Getting $Y / L$, as output per capita, and the logarithm of equation (1) for the steady state level of productivity and the rate of investment in physical capital $s_{k}$, the rate of employment growth $n$, and the level of human capital $h$. We also assume that $g$ and $\delta$ are constant across countries because $g$ reflects the rate of long run technological change and there is no strong reason to expect depreciation rates $\delta$ to vary seriously across countries. We also assume that $\ln [A]=a$ is constant and it may not differ across countries. Finally, $e$ represents a country-specific shock. Hence, the steady state level of log income per capita at a given time $t$ equals with the following:

$$
\ln \left(\frac{Y}{L}\right)_{t}=a_{t}+\frac{\alpha}{1-\alpha} \ln \left(s_{k}\right)_{t}-\frac{\alpha}{1-\alpha} \ln (n+g+\delta)_{t}+\frac{\beta}{1-\alpha} \ln (h)_{t}+\varepsilon_{t} .
$$

Descriptive analysis is only able to detect the direct contribution of structural shifts at industry level to aggregate economic and labour growth performance. After having demonstrated the existence of a systematic relationship between industrial structure of labour and income, we will examine the impact of human capital on economic growth per capita. Taking into account the new endogenous growth theories, our model includes the lagged dependent variables among the repressors. A dynamic specification requires exceptional instrumentation of these lagged endogenous variables, for which we engaged the empirically offered GMM estimators developed by Arellano - Bond (1991). These methods employ lagged levels of the dependent and predetermined variables as well as differences between the exogenous variables as instruments. In our dynamic model specifications, the economy tends toward long run equilibrium. The extent of economic growth generally affects the rate at which per capita output approaches its steady state value. After taking the first difference of the dependent variable of equation (2), we will test the following formula in each of the altered sectors:

$\Delta \ln Y_{i t}=\beta_{o}+\beta_{1} \Delta \ln Y_{i t-1}+\beta_{2} \ln \left(s_{k}\right)_{i t}+\beta_{3} \ln (n+g+\delta)_{i t}+\beta_{4} \ln (h)_{i t}+e_{i t}$.

The variables refer to the following: the dependent variable $Y_{i t}$ is the ratio of real GVA per capita of country $i$ for the period $t$ at a constant price (1995). The first independent variable refers to the lagged productivity growth and the next

Note: $\Delta v a r$ - variable in first differences, $\Delta v r_{t-1}$ - lagged differences, $\ln$ - in logarithm. 
one represents the share of investment $s_{k}$ within sectoral output. Thus, $n$ is the average growth rate of labour in each branch, which is also calculated from the KLEMS database. The rate of $g$ and depreciation $\delta$ are assumed to be constant (0.05), as in Mankiw et al. (1992). ${ }^{6} e$ is the error term.

A simple form of sensitivity analysis is recommended in order to check the robustness of our empirical findings. From this perspective, we examine the sample of years of education attained over the age of 25 from the PWT $(2014)^{7}$ and from the Barro-Lee Dataset (2014). In this case, we follow Hall - Jones (1999) and measure $h$ through the following formula:

$$
h=e^{\varphi(s)}
$$

where $s$ represents the average years of schooling, and the function $\varphi(s)$ is a loglinear relation between $h$ and $s$. Our calculation is based on Casseli's approach (2005:8), where the function $\varphi(s)$ is piecewise linear with a slope of 0.13 for $s \leq$ $4,0.10$ for $4<s \leq 8$, and 0.07 for $8<s$.

The coefficients of long run GVA per capita, investment share $s_{k}$, and engaged employment $n$ refer to the period between 1980 and 2007. The average years of schooling variables from the PWT (2014) are available per annum, but the BarroLee Database provides figures only for roughly every fifth year for each country. Hence, in order to compare the cross-country time-series of income, physical capital, employment and human capital are generated by averages of the periods between 1980, 1985, 1990, 1995, 2000, 2005 and 2007. All in all, in both cases we have an unbalanced panel date of the OECD-30 and OECD-20 country group ${ }^{8}$ to measure the existing relationship between human capital and long run GDP per capita in different labour-skilled branches.

Tables 3 and 4 represent $^{9}$ the corresponding results for the one-step GMM estimators. Although, theoretically, the two-step estimator should be preferred experimentally, both estimations appear to produce similar outcomes and we demonstrated the first one to assess the validity of sectoral comparisons. In the bottom section of these tables we also denoted the results of Arellano-Bond's AR(1) and the Sargan tests to demonstrate the result of autocorrelation and overidentifying restrictions. The significance levels of these tests in all models sug-

6 This assumption simplifies the fact that there is no relationship between innovation and human capital.

7 The index of human capital per person is based on years of schooling and returns to education by Psacharopoulos (1994).

8 EU-15 plus AUS, CAN, KOR, JPY, USA.

9 Additional descriptive statistics and correlation matrix of dependent variables is available in Tables 5 and 6. 
Table 3

Dynamic panel regression of real GVA per capita in each labour-skilled sector (1980-2007)

\begin{tabular}{|c|c|c|c|c|c|c|c|c|}
\hline \multicolumn{9}{|c|}{ Dependent variable: $\Delta \ln (\mathrm{GVA})_{i t}$} \\
\hline $\begin{array}{l}\text { Country } \\
\text { groups }\end{array}$ & OECD-30 & OECD-20 & OECD-30 & OECD-20 & OECD-30 & OECD-20 & OECD-30 & OECD-20 \\
\hline $\begin{array}{l}\text { Independent } \\
\text { variables }\end{array}$ & HS & HS & HIS & HIS & LIS & LIS & LS & LS \\
\hline Constant & $\begin{array}{c}-0.132 \\
(-7.99) * * *\end{array}$ & $\begin{array}{l}-0.372 \\
(-1.41)\end{array}$ & $\begin{array}{c}-0.329 \\
(-3.8)^{* * *}\end{array}$ & $\begin{array}{c}-0.459 \\
(-4.8)^{* * *}\end{array}$ & $\begin{array}{l}-0.132 \\
(-1.54)\end{array}$ & $\begin{array}{l}-0.132 \\
(-1.54)\end{array}$ & $\begin{array}{l}-0.068 \\
(-1.49)\end{array}$ & $\begin{array}{l}-0.068 \\
(-1.49)\end{array}$ \\
\hline$\Delta \ln (\mathrm{GVA})_{i t-1}$ & $\begin{array}{c}0.084 \\
(1.19)^{* * *}\end{array}$ & $\begin{array}{c}0.127 \\
(2.74)^{* * *}\end{array}$ & $\begin{array}{c}0.188 \\
(2.7)^{* * *}\end{array}$ & $\begin{array}{c}0.271 \\
(4.2)^{* * *}\end{array}$ & $\begin{array}{c}0.215 \\
\{4.50\}^{* *}\end{array}$ & $\begin{array}{c}0.215 \\
\{4.50\}^{* *}\end{array}$ & $\begin{array}{c}-0.103 \\
(-8.4)^{* * *}\end{array}$ & $\begin{array}{l}-0.015 \\
(-0.64) \\
\end{array}$ \\
\hline $\ln \left(s_{k}\right)_{i t}$ & $\begin{array}{c}0.086 \\
\{1.18\}^{* * *}\end{array}$ & $\begin{array}{c}0.09 \\
(3.5)^{* * *} \\
\end{array}$ & $\begin{array}{c}0.091 \\
(4.4)^{* * *} \\
\end{array}$ & $\begin{array}{c}0.158 \\
(5.5)^{* * *} \\
\end{array}$ & $\begin{array}{c}0.071 \\
(3.9)^{* * *} \\
\end{array}$ & $\begin{array}{c}0.071 \\
(3.9)^{* * *} \\
\end{array}$ & $\begin{array}{c}0.065 \\
(6.8)^{* * *}\end{array}$ & $\begin{array}{c}0.136 \\
(5.3)^{* * *} \\
\end{array}$ \\
\hline $\ln \left(n_{i}+g+\delta\right)_{i t}$ & $\begin{array}{c}-0.990 \\
(-17.65)^{* * *} \\
\end{array}$ & $\begin{array}{c}-0.993 \\
(-17.2)^{*} \\
\end{array}$ & $\begin{array}{c}-0.559 \\
(-9.3)^{* * *}\end{array}$ & $\begin{array}{c}-0.661 \\
(-8.7)^{* * *} \\
\end{array}$ & $\begin{array}{c}-1.08 \\
(-16.4)^{* * *} \\
\end{array}$ & $\begin{array}{c}-1.08 \\
(-16.4)^{* * *} \\
\end{array}$ & $\begin{array}{c}-0.671 \\
(-9.6)^{* * *} \\
\end{array}$ & $\begin{array}{c}-0.714 \\
(-10.7)^{* * *} \\
\end{array}$ \\
\hline $\ln (\text { school })_{i t}$ & $\begin{array}{l}0.051 \\
(0.72)\end{array}$ & $\begin{array}{l}0.164 \\
(0.64)\end{array}$ & $\begin{array}{c}0.058 \\
(2.13)^{* *}\end{array}$ & $\begin{array}{l}0.008 \\
-0.17\end{array}$ & $\begin{array}{c}-0.035 \\
(-2.97)^{* * *}\end{array}$ & $\begin{array}{c}-0.035 \\
(-2.97)^{* * *}\end{array}$ & $\begin{array}{c}-0.076 \\
(-2.00)^{* *}\end{array}$ & $\begin{array}{c}-0.057 \\
(-1.71)^{*}\end{array}$ \\
\hline $\begin{array}{l}\text { Number of } \\
\text { observations }\end{array}$ & 597 & 496 & 597 & 496 & 597 & 496 & 597 & 496 \\
\hline $\begin{array}{l}\text { Number of } \\
\text { countries }\end{array}$ & 30 & 20 & 30 & 20 & 30 & 20 & 30 & 20 \\
\hline $\begin{array}{l}\text { Number of } \\
\text { instruments }\end{array}$ & 29 & 29 & 29 & 29 & 29 & 29 & 29 & 29 \\
\hline Wald test & $320.23 * * *$ & $323.2 * * *$ & $88.1 * * *$ & $84.5^{* * *}$ & $273.3 * * *$ & $244.8 * * *$ & $123.5^{* * *}$ & $116.3^{* * *}$ \\
\hline AR test & $(-3.06)^{* * *}$ & $(-2.1)^{* * *}$ & $(-4.1)^{* * *}$ & $(-3.6)^{* * *}$ & $(-3.4)^{* * *}$ & $(-2.8)^{* * *}$ & $(-2.9)^{* * *}$ & $(-3.1)^{* * *}$ \\
\hline Sargan test & $141.84 * * *$ & $180.4^{* * *}$ & $71.3 * * *$ & $58.1 * * *$ & $35.1^{*}$ & $60.43 * * *$ & $49.34 * * *$ & $55.47 * * *$ \\
\hline
\end{tabular}

Source: Own calculation based on EC KLEMS (2014), PWT (2014).

Note: ${ }^{*}$ Heteroscedasticity robust z-statistics are in parentheses. *** significant at $1 \%, * * 5 \%,{ }^{*} 10 \%$, respectively. P-values without an index mean that the coefficient is not significant even at $10 \%$.

gested that the dynamic specification should be preferred (the only exception is HS sector in Table 4).

The impact of the lagged GVA per capita, however, is not robust in all of the examined sectors, ${ }^{10}$ but there are positive z-statistics in each of them. This affiliation, ceteris paribus, implies the existence of convergence among the examined OECD countries. According to the neoclassical growth theories, as expected, an

10 Lack of significance, in this case, means that changing investment does not indicate productivity growth in this branch at given level of output per capita and other determinants. 
Table 4

Dynamic panel regression of real GVA per capita in each labour-skilled sector (1980-2007)

\begin{tabular}{l|c|c|c|c}
\hline \multicolumn{5}{|c}{ Dependent variable: $\Delta \ln (\mathrm{GVA})_{i t}$} \\
\hline $\begin{array}{l}\text { Independent } \\
\text { variables }\end{array}$ & HS & HIS & LIS & LS \\
\hline constant & $\begin{array}{c}-0.623 \\
(-1.69)^{*}\end{array}$ & $\begin{array}{c}-0.221 \\
(-0.59)\end{array}$ & $\begin{array}{c}-0.807 \\
(-1.84)\end{array}$ & $\begin{array}{c}0.368 \\
(1.07)\end{array}$ \\
\hline$\Delta \ln (\mathrm{GVA})_{i t-1}$ & -0.345 & 0.429 & 0.248 & 0.303 \\
& $(-0.92)$ & $(1.60)^{*}$ & $(1.57)^{*}$ & $(1.76)^{*}$ \\
\hline $\ln \left(s_{k}\right)_{i t}$ & 0.15 & 0.19 & 0.404 & 0.034 \\
\hline $\ln \left(n_{i}+g+\delta\right)_{i t}$ & $(1.20)$ & $(1.41)$ & $(2.76)^{* * *}$ & $(0.34)$ \\
\hline $\ln (\text { school })_{i t}$ & -0.327 & -0.683 & -0.53 & -0.460 \\
& $(-1.8)^{*}$ & $(-3.42)^{* * *}$ & $(-3.35)^{* * *}$ & $(-2.81)^{* * *}$ \\
\hline Number of observations & 0.266 & -0.212 & -0.326 & -0.359 \\
\hline Number of countries & $(1.48)$ & $(1.12)^{* *}$ & $(-2.23)^{* *}$ & $(-2.93)^{* * *}$ \\
\hline Number of instruments & \multicolumn{3}{|c}{61} \\
\hline Wald test & $12.38^{* *}$ & $12.34^{* * *}$ & $13.61^{* * *}$ & $37.6^{* * *}$ \\
\hline AR test & $(0.34)$ & $(-2.81)^{* * *}$ & $(-1.83)^{*}$ & $(-2.09)^{* * *}$ \\
\hline Sargan test & 1.09 & $11.51^{* * *}$ & $6.33^{* *}$ & $3.88^{*}$ \\
\hline
\end{tabular}

Source: Own calculation based on EC KLEMS (2014), Heston et al. (2006).

Notes: * Heteroscedasticity robust $\mathrm{z}$-statistics are in parentheses. $* * *$ significant at $1 \%, * * 5 \%$, $* 10 \%$, respectively. P-values without an index mean that the coefficient is not significant even at the $10 \%$ level.

increase in the share of investment within output acts pro-cyclically and has a positive effect on productivity growth in both sectors. Thus, in our results, the employment growth attainment is negatively related to the growth of output per capita in the long run. The coefficients are ranged from circa $-0.3 \%$ to $-1 \%$. However, if employment increases in the high-skill intensive (HS) branches, it might affect productivity growth least of all.

In order to test the robustness of our estimation, we measure the impact of education on output per capita in different OECD country groups (Table 3) and replace the PWT (2014) time-series with another specific data of Heston et al. (2006) in Table 4. Essentially, the effect of human capital accumulation on productivity growth does not seem to be large. However, a $1 \%$ increase in the level of education results in an increase of productivity changes in the high-skilled (HS and HIS) branches, but the z-statistics is not significant. In the low-skilled 
Table 5

Descriptive statistics of the variables used in the regressions in each labour-skilled sector of OECD-30 countries (1980-2007)

HS

\begin{tabular}{l|c|c|c|c|c|c}
\hline Variable & Observation & Mean & Std. Dev. & Min & Max & Normality $^{(1)}$ \\
\hline$\Delta \ln (\mathrm{GVA})_{i t-1}$ & 657 & 0.014 & 0.039 & -0.347 & 0.375 & $1633.9^{* * *}$ \\
\hline $\ln \left(s_{k}\right)_{i t}$ & 772 & 3.141 & 0.240 & 1.941 & 3.823 & $62.3^{* * *}$ \\
\hline $\ln \left(n_{i}+g+\delta\right)_{i t}$ & 658 & 0.072 & 0.026 & -0.008 & 0.415 & $385.2^{* * *}$ \\
\hline $\ln (\text { school })_{i t}^{(2)}$ & 610 & 1.028 & 0.130 & 0.479 & 1.278 & $143.5^{* * *}$ \\
\hline
\end{tabular}

HIS

\begin{tabular}{l|c|c|c|c|c|c}
\hline Variable & Observation & Mean & Std. Dev. & Min & Max & Normality $^{(1)}$ \\
\hline$\Delta \ln (\mathrm{GVA})_{i t-1}$ & 657 & 0.023 & 0.042 & -0.143 & 0.302 & $216.8^{* * *}$ \\
\hline $\ln \left(s_{k}\right)_{i t}$ & 772 & 3.342 & 0.276 & 1.868 & 3.345 & $45.6^{* * *}$ \\
\hline $\ln \left(n_{i}+g+\delta\right)_{i t}$ & 658 & 0.066 & 0.027 & -0.026 & 0.191 & $139.1^{* * *}$ \\
\hline $\ln (\mathrm{school})_{i t}$ & 610 & 1.029 & 0.131 & 0.479 & 1.279 & $143.5^{* * *}$ \\
\hline
\end{tabular}

LIS

\begin{tabular}{l|c|c|c|c|c|c}
\hline Variable & Observation & Mean & Std. Dev. & Min & Max & Normality $^{(1)}$ \\
\hline$\Delta \ln (\mathrm{GVA})_{i t-1}$ & 657 & 0.022 & 0.033 & -0.090 & 0.189 & $89.5^{* * *}$ \\
\hline $\ln \left(s_{k}\right)_{i t}$ & 772 & 3.543 & 0.345 & 1.453 & 3.577 & $67.4^{* * *}$ \\
\hline $\ln \left(n_{i}+g+\delta\right)_{i t}$ & 658 & 0.059 & 0.030 & -0.085 & 0.212 & $166.4^{* * *}$ \\
\hline $\ln (\mathrm{school})_{i t}$ & 610 & 1.029 & 0.131 & 0.479 & 1.279 & $143.5^{* * *}$ \\
\hline
\end{tabular}

LS

\begin{tabular}{l|c|c|c|c|c|c}
\hline Variable & Observation & Mean & Std. Dev. & Min & Max & Normality $^{(1)}$ \\
\hline$\Delta \ln (\mathrm{GVA})_{i t-1}$ & 657 & 0.026 & 0.038 & -0.179 & 0.260 & $164.9^{* * *}$ \\
\hline $\ln \left(s_{k}\right)_{i t}$ & 772 & 3.549 & 0.411 & 1.567 & 3.545 & $67.8^{* * *}$ \\
\hline $\ln \left(n_{i}+g+\delta\right)_{i t}$ & 658 & 0.025 & 0.025 & -0.099 & 0.252 & $698.7^{* * *}$ \\
\hline $\ln (\text { school })_{i t}^{(2)}$ & 610 & 1.029 & 0.131 & 0.479 & 1.279 & $143.5^{* * *}$ \\
\hline
\end{tabular}

Source: Own calculation based on EC KLEMS (2014), PWT (2014).

Notes: (1) Doornik-Hansen test for multivariate normality. Letters in the upper index refer to significance: $* * *$ significance at $1 \%, * * 5 \%, * 10 \%$, respectively. P-values without an index mean that the coefficient is not significant even at the $10 \%$ level.

(LS and LIS) sectors human capital is negatively correlated with productivity growth in both models. ${ }^{11}$

11 The robustness was better when using PWT (2014), see the results of Wald-tests in Tables 3 and 4 . 
Table 6

The correlation matrix of dependent variables in each labour-skilled sector

\begin{tabular}{l|c|c|c|c}
\hline HS & $\Delta \ln (\mathrm{GVA})_{i t-1}$ & $\ln \left(s_{k}\right)_{i t}$ & $\ln \left(n_{i}+g+\delta\right)_{i t}$ & $\ln (\mathrm{school})_{i t}{ }^{(1)}$ \\
\hline Variables & 1.000 & & & \\
\hline$\Delta \ln (\mathrm{GVA})_{i t-1}$ & -0.066 & 1.000 & & \\
\hline $\ln \left(s_{k}\right)_{i t}$ & 0.047 & -0.019 & 1.000 & \\
\hline $\ln \left(n_{i}+g+\delta\right)_{i t}$ & 0.015 & -0.229 & 0.039 & 1.000 \\
\hline $\ln (\mathrm{school})_{i t}$ & & & & \\
\hline
\end{tabular}

HIS

\begin{tabular}{l|c|c|c|c}
\hline Variables & $\Delta \ln (\mathrm{GVA})_{i t-1}$ & $\ln \left(s_{k}\right)_{i t}$ & $\ln \left(n_{i}+g+\delta\right)_{i t}$ & $\ln (\mathrm{school})_{i t}{ }^{(1)}$ \\
\hline$\Delta \ln (\mathrm{GVA})_{i t-1}$ & 1.000 & & & \\
\hline $\ln \left(s_{k}\right)_{i t}$ & 0.111 & 1.000 & & \\
\hline $\ln \left(n_{i}+g+\delta\right)_{i t}$ & -0.341 & -0.219 & 1.000 & \\
\hline $\ln (\text { school })_{i t}$ & 0.007 & -0.219 & 0.038 & 1.000 \\
\hline
\end{tabular}

LIS

\begin{tabular}{l|c|c|c|c}
\hline Variables & $\Delta \ln (\mathrm{GVA})_{i t-1}$ & $\ln \left(s_{k}\right)_{i t}$ & $\ln \left(n_{i}+g+\delta\right)_{i t}$ & $\ln (\operatorname{school})_{i t}{ }^{(1)}$ \\
\hline$\Delta \ln (\mathrm{GVA})_{i t-1}$ & 1.000 & & & \\
\hline $\ln \left(s_{k}\right)_{i t}$ & 0.051 & 1.000 & & \\
\hline $\ln \left(n_{i}+g+\delta\right)_{i t}$ & -0.230 & -0.431 & 1.000 & \\
\hline $\ln (\mathrm{school})_{i t}$ & 0.008 & -0.176 & -0.090 & 1.000 \\
\hline
\end{tabular}

LS

\begin{tabular}{l|c|c|c|c}
\hline Variables & $\Delta \ln (\mathrm{GVA})_{i t-1}$ & $\ln \left(s_{k}\right)_{i t}$ & $\ln \left(n_{i}+g+\delta\right)_{i t}$ & $\ln (\mathrm{school})_{i t}{ }^{(1)}$ \\
\hline$\Delta \ln (\mathrm{GVA})_{i t-1}{ }^{(1)}$ & 1.000 & & & \\
\hline $\ln \left(s_{k}\right)_{i t}$ & 0.041 & 1.000 & & \\
\hline $\ln \left(n_{i}+g+\delta\right)_{i t}$ & -0.259 & -0.117 & 1.000 & \\
\hline $\ln \left({\text { school })_{i t}{ }^{(1)}}^{1}\right.$ & 0.132 & -0.208 & -0.135 & 1.000 \\
\hline
\end{tabular}

Source: Own calculation based on Equation (3) using EC KLEMS (2014), PWT (2014).

Moreover, it is possible that the quality of human capital is linked to employment. Thus, in the high-skilled (HS and HIS) sectors there was a positive, and in the low-skilled (LIS and LS) branches there was a negative correlation, which might directly impact controversially on aggregate productivity (see the correlation matrix of Tables 5-6). From this perspective, additional research is needed. 


\section{CONCLUSION}

Our first objective was to analyse employment growth and labour productivity tendencies for the period 1980-2007 in various OECD countries. The industrial structure was described by the distribution of value added and employment growth. In all of the examined countries the highest growth rate of output was in the high-skilled industries. The average annual employment growth rates in the higher skilled (HS and HIS) branches were higher than in the lower skilled (LIS and LS) sectors. The employment share increased in the high-skill intensive branches. All in all, it appears that higher levels of skills are linked to better economic performance. These tendencies anticipate the increasing role of human capital over the next decades; however, in spite of the decreasing demand for low-skilled workers, the proportion of high-skilled employees was still lower in these sectors.

The second objective was to examine the relationship between physical and human capital accumulation and output growth per capita. Our dynamic panel regression model yields a valid negative relationship between employment and productivity growth. We find that the high-skill intensive (HS) branches might affect productivity least of all. In consequence, we consider the following government policy suggestion for policymakers. Given that mainstream macro policies aim to promote stable long run economic growth, we could recommend assisting the high-skilled employment branches if this directly affects the economic demand structure. Essentially, the level of human capital is negatively correlated with productivity growth in low-skilled sectors. From this perspective, our analysis suggests that policymakers should try to increase the degree of competition in labour markets by motivating lower-skilled workers to learn more for enhancing better productivity growth.

An additional research direction has also emerged in this study. We argue that the institutional economic perspective is relevant since it extends the achievements and existing frontiers of macroeconomic theories. Although these approaches contend that labour institutions originated assumptions of growth, recently there have been serious debates in order to explain the role of institutions and how their interactions might influence productivity. However, no clear theoretical consensus has yet emerged and several unanswered problems remain. Hence, further research with our sectoral approach could be more fruitful. 


\section{REFERENCES}

Arellano, M. - Bond, S. (1991): Some Tests of Specification for Panel Data: Monte Carlo Evidence and an Application to Employment Equations. Review of Economic Studies, 58: 277-297.

van Ark, B. - Robinson, C. - Stokes, L. - Stuivenwold, E. (2003): Industry Structure and Taxonomies. In: O’Mahony, M. - van Ark, B. (ed.): EU Productivity and Competitiveness: An Industry Perspective. Can Europe Resume the Catching-up Process? European Commission, Italy, pp. $37-72$.

Barro, R.J. - Lee, J.W. (1993): Institutional Comparisons of Educational Attainment. Journal of Monetary Economics, 32(3): 363-394.

Barro, R.J. - Lee, J.W. (2014): Educational Attainment Dataset, http://www.barrolee.com/

Becker, G.S. (1964): Human Capital. New York: NBER.

Biagetti, M. - Scicchitano, S. (2013): The Determinants of Lifelong Learning Incidence across European Countries (Evidence from EU-SILC Data-set). Acta Oeconomica, 63(1): 77-98.

Casseli, F. (2005): Accounting for Cross-Country Income Differences. CEP Discussion Paper, No 667.

Czeglédi, P. (2010): Individual Rights as a Factor of Economic Convergence. Acta Oeconomica, 60(4): 375-403.

Dagum, C. - Slottje, D.J. (2000): A New Method to Estimate the Level and Distribution of Household Human Capital with Application. Structural Change and Economic Dynamics, 11(1-2): 67-94.

Denison, E.F. (1967): Why Growth Rates Differ: Postwar Experience in Nine Western Countries. Washington, D.C.: The Brookings Institution.

EC (2014): EU KLEMS Database, http://www.euklems.net/

Földvári, P. - Leeuwen, B. van (2008): Human Capital and Economic Growth in Asia 1890-2000: A Time-Series Analysis. Asian Economic Journal, 22(3): 225-240.

Földvári, P. - Leeuwen, B. van - Didenko, D. (2015): Capital Formation and Economic Growth under Central Planning and Transition: A Theoretical and Empirical Analysis, ca. 1920-2008. Acta Oeconomica, 65(1): 27-50.

Hall, R.E. - Jones, C.I. (1999): Why Do Some Countries Produce So Much More Output per Worker than Others? NBER Working Papers, 6564, National Bureau of Economic Research, Inc.

Heston, A. - Summers, R. - Aten, B. (2006): Penn World Table Version 6.2. Center for International Comparisons of Production, Income and Prices at the University of Pennsylvania.

Kendrick, J.W. (1976): The Formation and Stocks of Total Capital. New York: Columbia University Press for NBER.

Le, T. - Gibson, J. - Oxley, L. (2003): Cost- and Income-Based Measures of Human Capital. Journal of Economic Surveys, 17(3): 271-307.

Ljungberg, J. (2002): About the Role of Education in Swedish Economic Growth. Historical Social Research, 27(4): 125-139.

Mankiw, G.N. - Romer, P.M. - Weil, D.N. (1992): A Contribution to the Empirics of Economic Growth. The Quarterly Journal of Economics, 107(2): 407-437.

Nakamura, J.I. (1981): Human Capital Accumulation in Premodern Rural Japan. The Journal of Economic History, 41(2): 263-281.

Nunes, A.B. (2003): Government Expenditure on Education, Economic Growth and Long Waves: The Case of Portugal. Paedagogica Historica, 39(5): 559-581.

Psacharopoulos, G. (1994): Returns to Investment in Education: A Global Update. World Development, 22(9): 1325-1343. 
PWT (2014): Penn World Table 8.0 release (International Comparisons of Production, Income and Prices), http://citaotest01.housing.rug.nl/FebPwt/Dmn/AggregateXs.mvc/PivotShow (downloaded: 16.03.2014)

Schultz, T. (1961): Investment in Human Capital. American Economic Review, 51(1): 1-17.

Solow, R.M. (1956): A Contribution to the Theory of Economic Growth. The Quarterly Journal of Economics, 70(1): 65-94. 